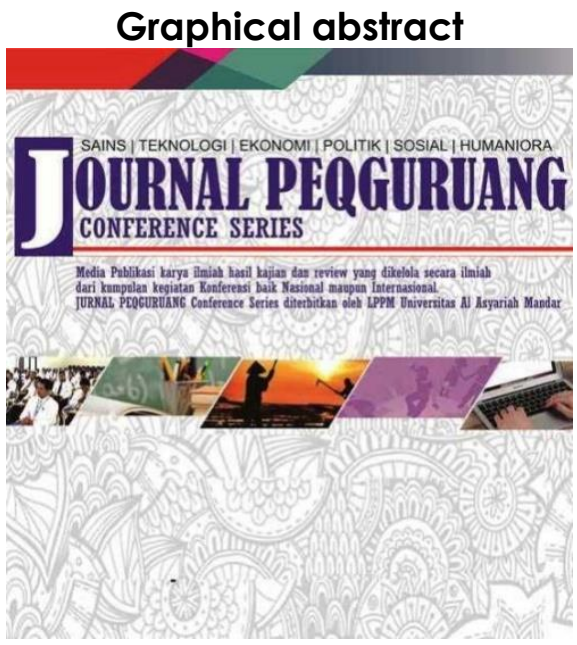

\title{
PENGARUH PEMBERIAN PUPUK NPK MUTIARA DAN SEKAM PADI TERHADAP PERTUMBUHAN DAN HASIL TANAMAN KUBIS BUNGA (Brassica Oleraceae Var. Botrytis L.)
}

\author{
${ }^{1 *}$ Korslinggo, ${ }^{2}$ Harli A. Karim, ${ }^{3}$ Satriani \\ Agrotektonologi, Fakultas Ilmu Pertanian, Universitas \\ Al Asyariah Mandar
}

Corresponding email:

Korslinggoolin@gmail.com

\begin{abstract}
Flower cabbage is a commodity with high economic volue so it is widely cultited in various countries including farmers in Indonesia. But the demand in the market is not balanced with the existing production because farmars' knowledge of rare cultivation, especially on maintenance is still lacking. So it is necessary to conduct research on the effect of appliying npk mutiara and rice husk on the growth ann yield of flower cabbage plants. This research augustust 2019 in Penatangan, Buntu Malangka. Kabupaten Mamasa. Aims to determine the effect of determine the effect of NPK Mutiara fertilizer and rice husk on growering pants. This study uses RAK with a structural pattern consisting of 3 factors : thefirst factor is the use of NPK Mutiara fertilizer with 3 levels, namely the use of NPK Mutiara fertilizer at a dose of $10 \mathrm{~g} /$ plant, $15 \mathrm{~g} /$ plant,and $20 \mathrm{~g} /$ plant. The scound factor is the use of rice husk fertilizer at three levels, namely without the use of rice husk, the use of rice husk at a dose of $150 \mathrm{~g} /$ plant and $300 \mathrm{~g} /$ plant. The results of this research showed that the interantion of NPK Mutiara fertilizer dosage and rice husk did not have a good affect on the parameters of plant height, number of leaves, time of flower formation, plant weight, and flower weight. On the growth and production of flower cabbage plants. But the highest yield was in the N2 treament, $15 \mathrm{~g}$ and S2 $300 \mathrm{~g}$, the use of NPK Mutiara fertilizerand rice husk did not have a significant effect on the parameters of plant height number of leaves, flower formation, plant weight and flower weight on the growth and production of flower cabbage plants, but the highest yield was in the use of NPK Mutiara $15 \mathrm{~g} /$ plants and the use of fertilizer $300 \mathrm{~g} /$ plant.

Keywords: NPK Mutiara, Sekam Padi, Kubis Bunga
\end{abstract}

Abstrak

Kubis bunga merupakan komoditas yang bernilai ekonomi tinggi sehingga diusahankan secara meluas di berbagai Negara termasuk petani yang ada di Indonesia. Namun Permintaan dipasaran tidak diimbangi dengan hasil produksi yang ada karna pengetahuan petani terhadap langka budidaya terutama pada pemeliharaan masih kurang. Sehingga perlu diadakan penelitian tentang pengaruh pemberian pupuk NPK mutiara dan sekam padi terhadap pertumbuhan dan hasil tanaman kubis bunga. Penelitian ini dilaksanakan pada bulan mei sampai pada bulan agustus 2019 di desa penatangan, kecamatan buntu malangka' kabupaten Mamasa, bertujuan untuk mengetahui pengaruh pemberian pupuk NPK mutiara dan sekam padi terhadap pertumbuhan dan hasil tanaman kubis bunga.Penelitian ini menggunakan RAK dengan pola factorial yang terdiri dari dua faktor yaitu faktor pertama yaitu penggunaan pupuk NPK mutiara dengan 3 taraf yaitu penggunaan pupuk NPK mutiara dengan dosis $10 \mathrm{gr} / \mathrm{tanaman}, 15 \mathrm{gr} / \mathrm{tanaman}$, dan 20 gr/tanaman. Faktor kedua yaitu penggunaan pupuk sekam padi dengan 3 taraf yaitu tanpa penggunaan sekam padi, penggunaan pupuk sekam padi dengan dosis $150 \mathrm{gr} / \mathrm{tanaman}$ dan $300 \mathrm{gr} /$ tanaman. Hasil penelitian ini menunjukkan bahwa tidak terdapat Interaksi dosis pupuk NPK mutiara dan sekam padi tidak memberikan pengaruh baik pada parameter tinggi tanaman, jumlah daun, waktu terbentuknya bunga, berat tanaman, dan berat bunga pada pertumbuhan dan produksi tanaman kubis bunga. Begitupun pada Penggunaan pupuk NPK mutiara dan sekam padi tidak memberikan pengaruh nyata terhadap parameter tersebut. Kata kunci :NPK Mutiara, Sekam Padi, Kubis Bunga 


\section{PENDAHULUAN}

Kubis bunga (Brassica oleracea var. botrytis L.) merupakan komoditas sayuran yang bernilai ekonomi tinggi sehingga diusahakan secara luas oleh petani di berbagai negara.Masyarakat di Indonesia menyebut kubis bunga sebagai kol kembang atau blum kol (berasal dari bahasa Belanda Bloemkool). Tanaman ini berasal dari Eropa subtropis di daerah Mediterania. Kubis bunga yang berwarna putih dengan massa bunga yang kompak seperti yang ditemukaan saat ini dikembangkan tahun 1866 oleh Mc.Mohan ahli benih dari Amerika. Diduga kubis bunga masuk ke Indonesia dari India pada abad ke XIX.(Juns, Zi. Gehel, 2012)

Gizi yang terkandung di dalam kubis bunga cukup baik bagi kesehatan tubuh manusia. Hasil penelitian Kementerian Kesehatan (2012) menyatakan bahwa dalam 100 gram kubis bunga terdapat kandungan energi sebesar 25 kilokalori, protein 24 gram, karbohidrat 4,9 gram, lemak 0,2 gram, kalsium 22 miligram, fosfor 72 miligram, dan zat besi 1 miligram. Selain itu, di dalam kubis bunga juga terkandung vitamin A sebanyak 90 IU, vitamin B1 0,11 miligram, dan vitamin C 96 miligram. Meskipun kubis bunga memiliki kandungan gizi yang baik, namun konsumen dari kubis bunga di Indonesia masih terbatas pada masyarakat menengah ke atas di kota-kota besar.Keterbatasan ini disebabkan oleh rendahnya produksi kubis bunga dalam negeri, selain itu harga jual kubis bunga yang mencapai Rp. 10.000 - Rp 15.000 per kilogram sulit dijangkau oleh masyarakat kecil.Tanaman ini dikenal sebagai salah satu tanaman dengan nilai ekonomis tinggi.budidaya kubis bunga tidak hanya dilakukan di dataran tinggi, namun beberapa kultivar dapat ditanam di dataran rendah sampai menengah. Varietas kubis bunga dataran rendah yang banyak dicari adalah varietas yang memiliki produktivitas tinggi, umur genjah, krop berbentuk kubah agak bulat, serta dapat beradaptasi dengan baik di dataran menengah antara 5001500 m dpl.(Marliah, $d k k, 2013$ ).

Permintaan yang tinggi terhadap kubis bunga tidak diiringi denganpeningkatan kuantitas produksi.Produksi kubis bunga di pasaran tidak stabil akibat pengetahuan petani terhadap teknik budidaya kubis bunga tergolong rendah. Kementan (2019) melaporkan bahwa tahun 20152019 produktivitas kubis bunga berturut-turut sebesar 10,58 ton $\mathrm{ha}^{-1}, 11,91$ ton $\mathrm{ha}^{-1}, 11,35$ ton $\mathrm{ha}^{-1}, 12,14$ ton ha ${ }^{-1}$, dan 12,68 ton ha $^{-1}$.

Salah satu kendala yang mendasar dalam budidaya tanaman di desa Penatangan adalah pengetahuan dan keterampilan petani tentang pemeliharaan tanaman. Hal ini dapat dibuktikan bahwa walaupun para petani telah menanam jenis / varietas yang sesuai dan ditunjang oleh syarat iklim yang baik, tetapi karena pemeliharaan yang kurang baik maka hasil yang diperoleh juga akan rendah. Salah satu aspek pemeliharaan yang perlu diperhatikan adalah pemupukan. Pemberian pupuk yang sesuai dengan kebutuhan tanaman baik makro maupun mikro diharapkan dapat mendorong proses pertumbuhan kubis bunga.
Pupuk digolongkan menjadi dua jenis yaitu pupuk organik dan pupuk anorganik. Pupuk anorganik memiliki kelebihan dalam memenuhi sifat kimia tanah seperti penambahan unsur hara yang tersedia di dalam tanah, tetapi penggunaan pupuk anorganik secara berlebihan akan berdampak terhadap penurunan kualitas tanah dan lingkungan. Salah satu jenis pupuk anorganik yang biasa digunakan dalam budidaya tanaman adalah pupuk NPK Majemuk sala satunya adalah pupuk NPK Mutiara. Karim H. A. Dkk. (2020) Dalam penelitiannya menjelaskan bahwa pemberian dosis pupuk kandang ayam 2.000 $\mathrm{kg} /$ hektar $^{-1}$ dan pemberian dosis pupuk npk 16 : 16 :16 $1.000 \mathrm{~kg} /$ hektar $^{-1}$ memberikan pengaruh terrbaik terhadap pertumbuhan dan hasil tanaman sawi pada parameter tinggi tanaman, jumlah daun, panjang daun, dan berat segar tanaman.

Sawi (Brassica juncea L.) termasuk sayuran daun mempunyai ekonomis dan kandungan gizi tinggi. Produksi sawi di Indonesia sebesar 602.468 ton dengan rata-rata produktifitasnya sebesar 9,91 ton/ha tahun 2014 . Masih rendah dibandingkan dengan produktivitas yang bisa mencapai 10-12 ton/ha.Masih rendahnya produktivitas tanaman disebabkan teknik budidaya khususnya pemupukan belum maksimal.Salah salah satu solusi yang bisa dilakukan adalah penggunaan bahan organik. Bahan organik sangat berperan pada pembentukan struktur tanah yang baik dan stabil sehingga infiltrasi dan kemampuan menyimpan air. Pemberian pupuk kandang memperbaiki sifat fisik tanah terutama struktur sehingga permeabilitas meningkat. Pemberian bahan organik juga berperan dalam memperbaiki sifat kimia tanah, selanjutnya penggunaan Pupuk NPK $16: 16$ : 16 juga mampu menjaga keseimbangan unsur hara makro dan mikro pada tanah. Penelitian ini bertujuan untuk mengetahui pengaruh berbagai dosis pupuk kandang ayam dan dosis NPK 16: 16 : 16 yang memberikan pengaruh terbaik terhadap pertumbuhan dan produksi sawi.

Dalam program manajemen kesuburan tanah yang baik, lima faktor yang memengaruhi keberhasilan pemupukan agar tanaman dapat tumbuh dengan optimal. Dalam istilah pemupukan hal tersebut dinamakan lima tepat pemupukan yaitu: tepat jenis, tepat dosis, tepat waktu, tepat tempat, dan tepat cara. Nutrisi utama yang dibutuhkan oleh tanaman adalah nitrogen $(\mathrm{N})$, fosfor $(\mathrm{P})$, dan kalium (K). Pasokan yang tidak memadai dari setiap nutrisi selama pertumbuhan tanaman akan memiliki dampak negatif pada kemampuan reproduksi, pertumbuhan, dan hasil tanaman (Firmansyah, Iman. Dkk. 2017)

Pemupukan adalah penerapan bahan atau unsurunsur kimia organik maupun anorganik yang ditujukan untuk memperbaiki kondisi kimia tanah dan memenuhi kebutuhan unsur hara bagi tanaman sehingga dapat meningkatkan produktivitas tanaman. Pupuk tidak tersimpan didalam tanah dalam jangka waktu yang lama sehingga pemupukan perlu dilakukan sehingga unsur hara bagi tanaman tetap tersedia, namun Pemupukan dengan bahan anorganik yang tidak tepat dan tidak 
berimbang serta dalam pemakaian jangka panjang dapat menurunkan pH tanah Gomes, L. dkk.(2012)

Penambahan bahan organik diantaranya dapat dilakukan dengan pemberian kompos, baik yang berasal dari kotoran hewan seperti kotoran ayam maupun sisasisa limbah produksi pertanian misalnya limbah sekam padi.Sekam padi tersusun atas berbagai unsur logam dan nonlogam. Kandungan unsur karbon, oksigen, dan silikon dalam sekam padi lebih dominan dibanding dengan unsur yang lain

Limbah sekam padi dan pupuk NPK Mutiara belum dimanfaatkan secara obtimal oleh masyarakat di desa penatangan, serta tanaman kubis bunga belum dikenal oleh masyarakat. Berdasarkan hal tersebut diatas, maka dilakukan penelitian dengan judul Pengaruh Pupuk NPK Dan Media Sekam Terhadap Pertumbuhan Dan Hasil Tanaman Kubis Bunga (Brassica oleracea var botrytis).

\section{METODE PENELITIAN}

Penelitian ini dilaksanakan di Desa Penatangan, Kecamatan Buntu Malangka', Kabupatan Mamasa, yang berlangsung dari bulan Mei sampai Agustus 2019. Penelitian ini dilaksanakan dalam bentuk Rancangan Acak Kelompok (RAK) dengan pola faktorial yang terdiri dari dua factor yaitu. Faktor pertama adalah dosis pupuk NPK Mutiara dengan 3 taraf yaitu:

N1 = pemberian pupuk NPK Mutiara dengan dosis $10 \mathrm{~g} /$ pohon $\mathrm{N} 2=$ pemberian pupuk NPK Mutiara dengan dosis $15 \mathrm{~g} /$ pohon N3 = pemberian pupuk NPK Mutiara dengan dosis $20 \mathrm{~g} /$ pohon Faktor kedua adalah penggunaan sekam padi dengan 3 taraf yaitu

S0 = tanpa pemberian sekam padi

$\mathrm{S} 1$ = pemberian sekam padi dengan dosis $150 \mathrm{~g} /$ tanaman

$\mathrm{S} 2=$ pemberian sekam padi dengan dosis $300 \mathrm{~g} /$ tanaman

Sehingga terdapat 9 kombinasi perlakuan adalah sebagai berikut: N1S0, N1S1, N1S2, N2S0, N2S1, N2S2, N3S0, N3S1, N3S2. Setiap kombinasi perlakuan diulang empat kali sehingga terdapat 36 unit perlakuan. Setiap unit perlakuan menggunakan 3 tanaman, dengan demikian jumlah keseluruhan yang digunakan adalah 108 tanaman.

\section{HASIL DAN PEMBAHASAN Tinggi Tanaman}

Gidik ragam menunjukkan bahwa pemberian pupuk NPK Mutiara ( N ) tidak memberikan penguruh nyata, pemberian Sekam Padi (S) juga tidak berpengaruh nyata, demikian pula dengan interaksi pemberian pupuk NPK Mutiara dan Sekam Padi ( N x S ) juga tidak berpengaruh nyata terhadap tinggi tanaman kubis bunga, seperti pada gambar 1.

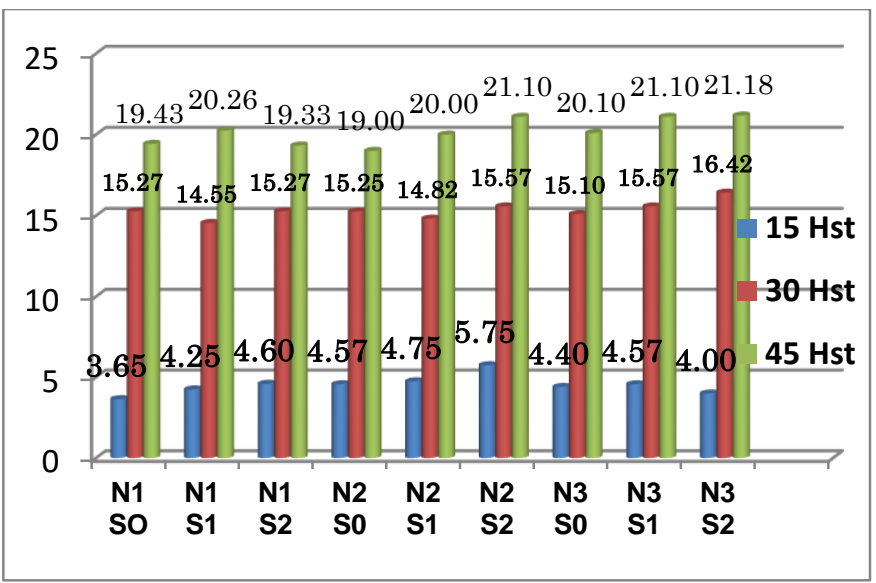

Gambar 1. Histogram rata-rata tinggi tanaman $(\mathrm{cm})$ pada pemberian pupuk NPK Mutiara dan sekam padi terhadap pertumbuhan dan hasil tanaman kubis bunga pada umur 15 HST, 30 HST dan 45 HST

Gambar 1. Menunjukkan bahwa rata-rata tertinggi pada parameter tinggi tanaman yaitu umur 15 Hst adalah $5.75 \mathrm{~cm}$ yaitu pada pemberian pupuk NPK Mutiara dosis 15 gram dan sekam padi dengan takaran 300 gram (N2S2) dan terrendah pada pemberian pupuk NPK Mutiara 10 gram dan tanpa pemberian sekam padi, sedangkan 30 HST dan 45 HST dengan masing - masing tinggi $16.42 \mathrm{~cm}$ dan 21.18 yaitu pada pemberian pupuk npk mutiara dosis 20 gram dan sekam padi dengan takaran 300 gram (N3S2) dan terendah yaitu pada umur 30 HST pada pemberian NPK mutiara 10 gram dan sekam padi 150 gram (N1S1) yaitu $15.55 \mathrm{~cm}, 45 \mathrm{HST}$ pada pemberian NPK Mutiara 10 gram dan sekam padi 300 gram (N1S2) yaitu $19.33 \mathrm{~cm}$

Jumlah Daun

Sidik ragam menunjukkan bahwa dosis pupuk NPK Mutiara (N) tidak memberikan pengaruh nyata, Sekam Padi ( S ) juga tidak berpengaruh nyata, demikian pula dengan interaksi antara dosis pupuk NPK Mutiara dan Sekam Padi ( NxS) tidak perpengaruh nyata terhadap jumlah daun, seperti pada gambar 2 .

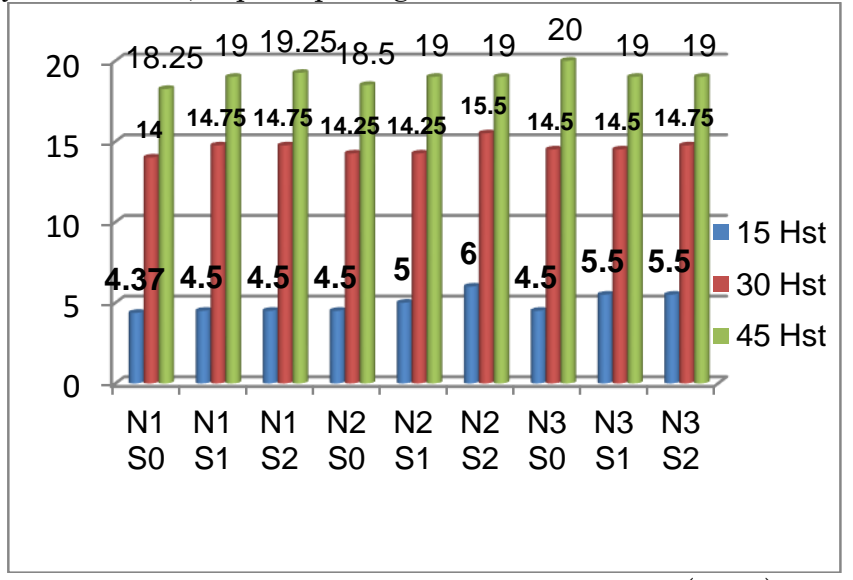

Gambar 2. Rata-rata jumlah daun tanaman (helai) pada pemberian pupuk NPK Mutiara dan Sekam Padi terhadap pertumbuhan dan hasil tanaman kubis bunga pada umur 15 HST, 30 HST dan 45 HST 
Gambar 1. Menunjukkan bahwa rata-rata tertinggi pada parameter jumlah daun yaitu umur 15 HST dan 30 HST yaitu masing HST 6.00 helai dan 15.50 helai yaitu pada pemberian pupuk NPK Mutiara 15 gram, dan sekam padi 300 gram (N2S2), dan pada umur 45 HST yaitu pada pemberian NPK mutiara 20 gram dan tanpa pemberian pupuk sekam padi (N2S0) sedangkan terendah ada pada perlakuan N1S0 (penggunaan N 15 gram dan tanpa penggunaan sekam padi) baik 15 HST, 30 HST maupun 45 HST.

\section{Terbentuknya Bunga}

Sidik ragam menunjukkan bahwa penggunaan pupuk NPK Mutiara (N) tidak memberikan pengaruh nyata, pemberian Sekam Padi (S) juga tidak berpengaruh nyata, demikian pula dengan interaksi dosis pupuk npk mutiara dan sekam padi $(\mathrm{NxS})$ juga tidak berpengaruh nyata terhadap waktu terbentuknya bunga.

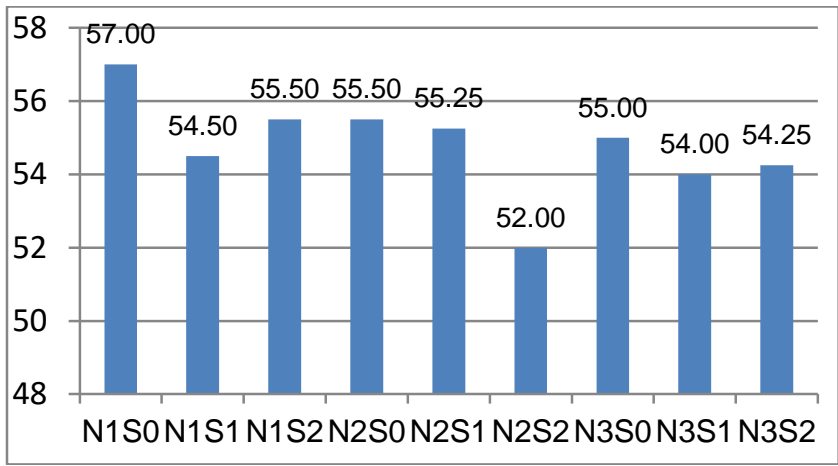

Gambar 3. Histogram rata-rata waktu terbentuknya bunga (HST) pada pemberian pupuk NPK Mutiaradan Sekam Padi terhadap pertumbuhan dan hasil tanaman kubis bunga

Gambar 1. Menunjukkan bahwa rata-rata tertinggi pada parameter terbentuknya bunga yaitu 52.00 HST yaitu pada pemberian pupuk NPK Mutiara 15 gram dan sekam padi 300 gram/ tanaman (N2S2), sedangkan yang terendah yaitu 57 HST pada pemberian pupuk NPK Mutiara 10 gr $(\mathrm{N})$ dan tanpa pemberian sekam padi.

\section{Berat Tanaman}

Data pengamatan berat tanaman dan sidik ragamnya disajikan pada tabel 8.a dan 8.b. sidik ragam menunjukkan bahwa dosis pupuk NPK Mutiara (N) tidak memberikan pengaruh nyata, Sekam Padi (S) juga tidak berpengaruh nyata, demikian pula dengan interaksi dosis pupuk NPK Mutiara dan Sekam Padi (NxS) juga tidak berpengaruh nyata terhadap berat tanaman, seperti pada gambar 4.

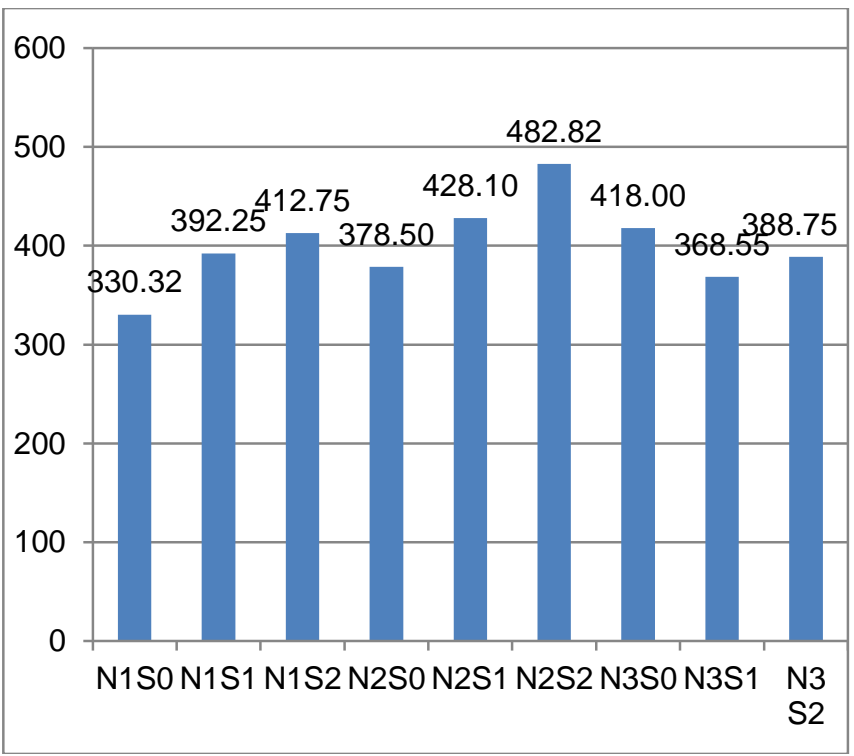

Gambar 4. Histogram rata-rata berat tanaman (g) pada pemberian pupuk NPK Mutiara dan Sekam Padi terhadap pertumbuhan dan hasil tanaman kubis bunga

Histogram rata-rata berat tanaman pada dosis pemberian pupuk NPK Mutiara dan Sekam Padi terhadap pertumbuhan dan hasil tanaman kubis bunga menunjukkan bahwa yang terberat tanamannya sebanyak 482.82 garam yaitu pada pemberian pupuk NPK Mutiara 15 gram dan sekam padi 300 gram/ pohonnya (N2S2).

\section{Berat Bunga}

Sidik ragam menunjukkan bahwa pemberian pupuk NPK Mutiara tidak memberiakan pengaruh nyata, sekam padi juga tidak berpengaruh nyata (S), demikian pula dengan interaksi antara pupuk NPK Mutiara dan sekam padi $(\mathrm{NxS})$ juga tidak berpengaruh nyata terhadap berat bunga, seperti pada gambar 5 .

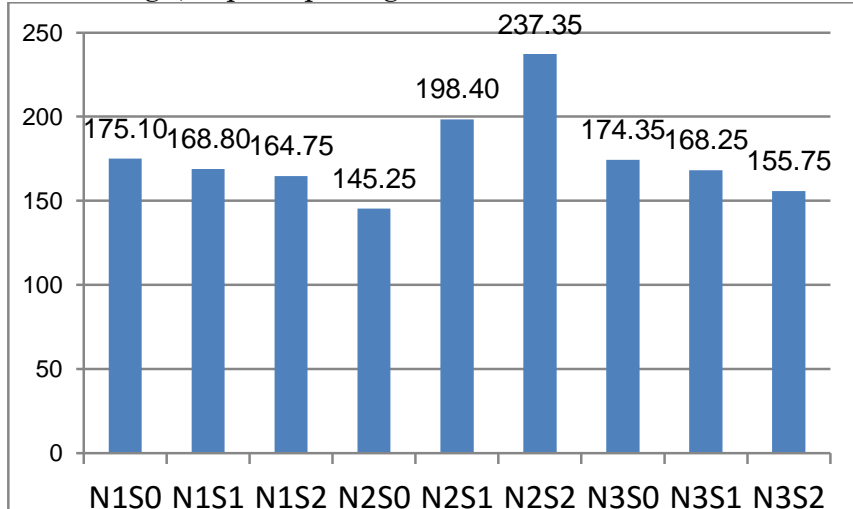

Gambar 5. Histogram rata-rata berat bunga (g) pada pemberian pupuk NPK Mutiara dan Sekam Padi terhadap pertumbuhan dan hasil tanaman kubis bunga

Gambar 5. Menunjukkan bahwa rata-rata tertinggi pada parameter berat bunga yaitu 237.35 gram yaitu pada peberian pupuk NPK Mutiara 15 gram dan 
sekam padi 300 gram (N2S2) dan terendah ada pada penggunaan pupuk NPK Mutiara 15 gram (N2) dan tanpa menggunakan sekam padi (S0).

\section{Pembahasan}

Upaya perbaikan pertumbuhan dan peningkatan produksi pertanian sala satunya dilakukan melalui penerapan input teknologi penerapan sistem budidaya yang sehat dengan tetap mempertimbangkan faktor lingkungan dan menjaga kelestarian ekosistem alami.

Hasil penelitian menunjukkan bahwa dosis pemberian pupuk NPK Mutiara dan sekam padi tidak memberikan pengaruh baik terhadap parameter tinggi tanaman, jumlah daun, waktu terbentuknya bunga, berat tanaman dan berat bunga. Hal ini diduga karena jarak dosis pupuk antara perlakuan berdekatan sehingga pertumbuhan tanaman hamper seragam. Pupuk NPK mutiara dan sekam padi berbentuk padat yang dalam penyerapannya mengalami proses penguraian dalam hal ini membutuhkan waktu, Selain itu tempat media yang digunakan dalam penelitian ini adalah polybag sehingga pupuk NPK mutiara dan sekam padi dalam polybag tersebut terbawah keluar oleh air hujan maupun air siraman yang belum sempat diserap oleh akar tanaman kubis bunga. Air berfungsi sebagai media gerak hara ke akar - akartanaman.Akan tetapi bila Air terlalu banyak hara - hara yang mobil dapat hilang tercuci dari lingkungan perakaran. (Pujiwati Istirochah, 2019).

Bahan yang diberikan pada tanaman sangat tergantung pada kebutuhan, dosis dan waktu serta jenis bahan yang di tunjukkan untuk perbaikan pertumbuhan dan peningkangkatan produksi tanaman namun kembali pada komposisi penyusun dari bahan yang diberikan. Mengacu pada hal tersebut, dalam penelitian ini hasil menunjukkan bahwa komponen pengamatan pertumbuhan maupun produksi tidak memberikan pengaruh baik pada kubis bunga karna meskipun bahan yang diberikan yaitu anorganik dan organik bisa saling melengkapi namun komposisi penyusunnya terdiri dari bahan padat dimana proses penyerapannya membutuhkan waktu sehingga pemberian pupuk dengan harapan dapat memenuhi kebutuhan tanaman kubis bunga akan nutrisi dari dalam akar untuk menunjang pertumbuhan dan perkembangan tanaman kurang memadai.

Ruubi Azalea (2018) dalam bukunya menegaskan bahwa dalam bidang pertanian, air merupakan kebutuhan pokok yang mutlak dibutuhkan bagi kehidupan tanaman.Kekurangan air pada usaha pertanian dapat memberikan dampak kerugian yang sangat besar. Dalam waktu yang relatif singkat, tanaman yang kekurangan air akan mati lebih cepat jika dibandingkan dengan tanaman yang kekurangan zat makanan. Sehingga berdasarkan hasil penelitian tinggi tanaman, jumlah daun, terbentuknya bunga, berat tanaman, dan berat bunga, input yang diberikan tidak memberikan pengaruh namun tanaman tetap melangsungkan proses pertumbuhan karena didalam tanah tersedia air, disamping tanaman juga tetap dilakukan proses pemeliharaan yang sala satu cukupannya adalah penyiraman sehingga tanaman tetap dalam kondisi yang segar dan tidak kekurangan air.
Hasil penelitian menunjukkan bahwa pemberian pupuk NPK mutiara 15 gr/tanaman ( N2 ), menunjukkan hasil terbaik pada parameter terbentuknya bunga (rata rata $52 \mathrm{HST}$ ), berat tanaman ( rata - rata $502.82 \mathrm{~g}$ ), dan berat bunga ( rata - rata 237.35 g) meskipun belum siknifikan. Pupuk NPK mengandung lima unsur yang sangat dibutuhkan tanaman yaitu nitrogen, phosphate, kalium, magnesium, dan kalsium. Sala satu kegunaan pupuk NPK yaitu memperkuat perakaran, mengurangi kerontokan bunga dan buah.Narka, I. wayan ( 2016 ) mengemukakan, Pupuk NPK Mutiara mengandung 16\% N (Nitrogen), 16\% P2O5 (Phospate), 16\% K2O (Kalium), 0.5\% $\mathrm{MgO}$ (Magnesium), dan 6\% CaO (Kalsium). Karena kandungan tersebut pupuk ini juga dikenal dengan istilah pupuk NPK 16-16-16. Pupuk NPK Mutiara memiliki keunggulan seperti Mengandung unsur hara NPK sekaligus hara mikro $\mathrm{CaO}$ dan $\mathrm{MgO}$ yang sangat dibutuhkan tanaman, Menjaga keseimbangan unsur hara makro dan mikro pada tanah, Pengapliaksiannya yang cukup mudah sehingga biaya pemupukan relative lebih kecil, dan dapat digunakan untuk semua tanaman (pangan, hortikultura, perkebunan).

Hasil penelitian menunjukkan pemberian pupuk sekam padi $300 \mathrm{~g} /$ tanaman ( S2 ) menunjukkan hasil tertinggi pada parameter tinggi tanaman (rata-rata 21.175 $\mathrm{cm} /$ tanaman), berat tanaman (rata-rata $502.82 \mathrm{~g} /$ tanaman), dan berat bunga ( rata - rata $237.35 \mathrm{~g} /$ tanaman). Pupuk sekam padi adalah sala satu pupuk organik yang dapat memperbaiki struktur tanah, dan memperbaiki tingkat keasaman tanah.Dalam penelitian sekam padi memberi dampak terhadap pertumbuhan dan hasil tanaman kubis bunga namun belum signifikan. Anonim, (2011) menjelaskan bahwa sekam padi mengandung SiO2 (52\%), C (31\%), K (0.3\%), N (0,18\%), F $(0,08 \%)$, dan kalsium (0,14\%). Selain itu juga mengandung unsur lain seperti $\mathrm{Fe} 2 \mathrm{O} 3, \mathrm{~K} 2 \mathrm{O}, \mathrm{MgO}, \mathrm{CaO}, \mathrm{MnO}$ dan $\mathrm{Cu}$ dalam jumlah yang kecil serta beberapa jenis bahan organik. Kandungan silikat yang tinggi dapat menguntungkan bagi tanaman karena menjadi lebih tahan terhadap hama dan penyakit akibat adanya pengerasan jaringan. Sekam padi juga digunakan untuk menambah kadar Kalium dalam tanah.

Tanaman kubis bunga merupakan tanaman yang fase produksinya ada pada bunga atau yang menjadi economy yieldnya adalah pada bagian bunga tanaman, yang terbukti dalam penelitian ini tanaman kubis bunga dalam menyelesaikan daur hidupnya dengan hasil ahir berupa berat bunga yang sekaligus merupakan biommas tanaman dan hal ini terjadi karna tanaman memanfatkan bahan - bahan yang tersedia dalam tanah maupun yang bersumber dari udara sehingga tanaman tetap melakukan aktifitas yang menjadi kata kunci dari semua organisme tanaman yaitu fotosintesis artinya bahwa adanya pemanfaatan klorofil atau semua yang berwarna hijau pada tanaman dengan suplei hara maupun air dari tanah sehingga tanaman tetap menghasilkan produk hasil fotosintesis pada kubis bunga berupa tinggi tanaman, jumlah daun, terbentuknya bunga, berat tanaman dan berat bunga. Ruubi Azalea (2018) mengemukakan bahwa sinar matahari dibutuhkan tanaman sebagai sumber 
energi dalam proses asimilasi untuk menghasilkan bagian vegetatif, misalnya daun, batang, serta bagian generatif seperti bunga ataupun biji. Kurangnya intensitas sinar matahari akan menghambat pertumbuhan dan hasil tanaman, hal ini berdampak pada turunnya hasil produksi.

Pupuk yang diberikan yaitu NPK mutiara dan sekam padi yang berbahan padat dengan komposisi unsur makro dan mikro belum sepenuhnya dimanfaatkan oleh kubis bunga karna pupuk sekam padi merupakan pupuk organik dimana sifat utama pupuk organik kondisi awalnya ditujukan pada perbaikan media tumbuh tanaman dalam hal ini perbaikan sifat fisik, kimia dan biologi tanah sedangkan NPK mutiara merupakan pupukKementan. 2019. Data Lima Tahun Terahir-Kementrian anorganik berbentuk butiran dimana proses penyerapannya oleh tanaman membutuhkan waktu sehingga pada penggunaan awalnya sekam padi dan NPK mutiara pada tanaman kubis bunga belum tampak responnya namun dalam jangka waktu tertentu kemudian akan nampak respon dan hasilnya pada perbaikan pertumbuhan dan peningkatan produksi.

\section{SIMPULAN}

Dari hasil penelitian dapat disimpulkan:

1. Tidak terdapat Interaksi antara dosis pupuk NPK mutiara dan sekam padi yang memberikan pengaruh nyata pada parameter tinggi tanaman, jumlah daun, waktu terbentuknya bunga, berat tanaman, dan berat bunga pada pertumbuhan dan produksi tanaman kubis bunga. Namun tertinggi ada pada perlakuan N2S2 ( N2, 15 gr dan S2, 300 gr )

2. Tidak terdapat dosis pupuk NPK mutiara yang memberikan pengaruh nyata terhadap parameter tinggi tanaman, jumlah daun, waktu terbentuknya bunga, berat tanaman, dan berat bunga pada pertumbuhan dan produksi tanaman kubis bunga.

3. Tidak terdapat dosis sekam padi yang memberikan pengaruh nyata terhadap parameter tinggi tanaman, jumlah daun, waktu terbentuknya bunga, berat tanaman, dan berat bunga pada pertumbuhan dan produksi tanaman kubis bunga.

\section{Saran}

Dalam rangka perbaikan pertumbuhan dan produksi kubis bunga pada penggunaan pupuk NPK mutiara dan sekam padi, disarankan disarankan untuk penelitian dengan dosis dan kombinasi yang lain.

\section{DAFTAR PUSTAKA}

Anonim. 2011. Dalam Dewi Septiani. 2012. Pengaruh Pemberian Arang Sekam Padi Terhadap Pertumbuhan Dan Hasil Tanaman Cabai Rawit.politeknik negeri lampung.

Digilib.unila.ac.id

Firmansyah, Iman. Dkk. 2017.Pengaruh Kombinasi Dosis Pupuk N, P, Dan K Terhadap Pertumbuhan Dan Hasil Tanaman Terung (Solanum Melongena L.).Badan Penelitian dan Pengembangan Pertanian.Jakartaselatan. https://media.neliti.com>publications
Gomes, L. dkk.2012. Pengaruh Pupuk Organik Cair Ri1 Terhadap Pertumbuhan DanProduksi Tanaman Kubis Bunga (Brassica Oleracea Var. Botrytis L.). Universitas Pattimura. Ambon. Jurnal budidaya tanaman, vol 1. https//ojs.unpatti.ac.id

Juns, Zi. Gehel.2012. Tehnik budidaya kubis bunga (Brassica Oleraceae Var Botrytis L.)BBPP Lembabang. Artikel pertanian www.bbpp-lembang.info.arsip.artikel

H. A., dkk (2020). Peningkatan Produktifitas Tanaman Sawi Melalui Penambahan Pupuk Kandang Ayam dan NPK 16: 16: 16. JAMI : Jurnal Ahli Muda Indonesia, 1 (1), 65-72.

Pertanian https://www.pertanian.go.id

Kementrian Kesehatan. 2012. Undang-undang republicIndonesia nomor 18 tahun 2012 tentang pangan. http://www.hukor.depkes.go.id

Marliah et al., 2013. Dalam Aptika Hana Prastiwi Nareswari. 2018. Peningkatan Hasil Genotipe Tanaman Kubis Bunga Dataran Rendah Dengan Aplikasi Pupuk Secara Fertigasi Melalui Irigasi Tetes. Departemen Agronomi dan Hortikultura. Fakultas Pertanian. Institut Pertanian Bogor. Bogor.

Narka, I. Wayan (2016). Pemberian Kombinasi Dosis Pupuk Hayati Evagrow dan Pupuk Kimia NPK terhadap pertumbuhan tanaman bunga gumitir. Universitas udayana. https://simdos.unud.ac.id

Pujiwati, Istirochah. 2019. Pengantar Fisiologi Tumbuhan. Penerbit Intimedia. Jl. Joyosuko Metro 42 Malang. Jawa Timur

Rachmi, Nur. Lulu. 2017. Optimasi Metode Adsorpsi Menggunakan Silika Sekam Padi Untuk Analisa Senyawa Polisiklik Aromatik Hidrokarbon (Pah). Universitas Lampung. Bandar Lampung. Digilib.unila.ac.id

Ruubi, Azalea. 2018. Brokoli: Tehnik Budidaya Dan Analisis Usaha. Penerbit: Trans Idea Publishing. Sleman, Yogyakarta. 